\title{
Trade and conservation of medicinal and aromatic plants in western Nepal
}

\author{
Dipesh Pyakurel ${ }^{1,2 *}$, Indira Bhattarai (Sharma) ${ }^{1}$ and Suresh Kumar Ghimire ${ }^{3}$ \\ ${ }^{1}$ Faculty of Agriculture, Agriculture and Forestry University, Nepal \\ ${ }^{2}$ Faculty of Science, University of Copenhagen, Denmark \\ ${ }^{3}$ Central Department of Botany, Tribhuvan University, Nepal
}

\begin{abstract}
This paper quantifies the volume and value of medicinal and aromatic plants (MAPs) traded from Baitadi district in western Nepal Information related to trade, in the Fiscal Year 2014/015, was collected through pre-tested structured questionnaire. Harvesters ( $n$ $=24)$ and the entire population of sub-local $(n=35)$ and local $(n=7)$ traders were interviewed to quantify the value and volume of MAP trade from the district. Results showed that $15.2 \%$ households were engaged in harvesting of MAPs for trade, contributing 9.5\% of the total cash income giving an impression that MAPs provide supplementary source of income. A total of 731.5 tons of MAPs, comprising 17 products (from 17 species) with total value of NRs 31.3 million (US\$315,175) was traded from the district. Rittha (Sapindus mukorossi), tejpat (Cinnamomum tamala) and pakhanved (Bergenia ciliata) were traded in higher amounts, representing 356.5, 171.0 and 70.0 tons, respectively. The cumulative value of trade was highest for satuwa (Paris polyphylla) with NRs 7.7 million. Nepalgunj is the favoured 'transit' city for the export of MAPs to India accounting for more than $82 \%$ of MAPs sourced from Baitadi. Satuwa has been identified as the most vulnerable species mainly due to premature and over-harvesting in response to high price and growing regional demand coupled with slow growth and high habitat specificity that may results in impaired population growth thus demanding a detailed bio-physical studies. The study finds that strict regulatory mechanism like ban proves to be less effective in species conservation and suggest adopting alternative management strategies.
\end{abstract}

Key-words: Baitadi, harvesters, income, MAP trade, Paris polyphylla, traders, wholesalers.

\section{Introduction}

Millions of people around the globe depend on forest resources for cultural needs and to diversify their source of income (Shackleton et al. 2011). The dependency is even higher in developing countries where people rely on forest resources especially for food, fuel, fodder, medicine and construction materials to meet subsistence needs and generate cash income (Sunderlin et al. 2005). Angelsen et al. (2014) reported that $28 \%$ of total household income in developing countries come from environmental resources, out of which $77 \%$ from the natural forests. Medicinal and aromatic plants (MAPs), a subset of non-timber forest products, are one of the major forest resources offering rural communities to generate cash income (Ruiz Pérez and Byron 1999; Shackleton and Shackleton 2004). The importance of MAPs is even higher in recent years with the expansion of global herbal market, as Vasisht et al. (2016) estimated the annual trade of MAP materials to be US\$ 33 billion in 2014

MAPs from the Himalayan region are harvested to cure various ailments since millennia as described in 4500 years old Rigveda (Malla and Shakya 1999). Ayurvedic system in India, that dates back to 3000 years, sourced medicinal plants from the Himalayan region (Farnsworth and Soejarto 1991).
Nepal's position in the centre of the Himalaya enables it to host thousands of medicinal plants and is one of the major suppliers of MAPs to India since time immemorial. However, the quantification of trade had started few decades ago when Edwards (1996) estimated 10,000 tons of MAPs from more than 100 species was harvested in and from Nepal. Few years later, Olsen (2005); based on 1997/98 survey, estimated the export of 14500 tons of crude MAPs worth US\$ 16 million to India and China. Recently, using the UN COMTRADE data, Ghimire et al. (2015) estimated the export of 10770 tons of MAPs worth US\$ 60.09 million from Nepal in 2014. Likewise, several other trade-related studies were conducted in the past few decades that focused on (i) quantifying trade of specific MAP products of a district (e.g., Hertog and Wiersum 2000; Maraseni et al. 2006; Koirala et al. 2010; Shrestha and Bawa 2013); (ii) listing the traded MAPs of a district without quantification (e.g., Pandit and Thapa 2003; Bista and Webb 2006); or (iii) listing the traded MAPs of Nepal (e.g., Bhattarai and Ghimire 2006). However, there are very few studies (e.g., Olsen 1998; Humagain and Shrestha 2009) that quantifies the traded MAPs at district level in Nepal. The comprehensive district level trade studies help to understand the livelihoods implications, estimate the contribution of forest products

${ }^{*}$ Corresponding author: e-mail - dipeshpyakurel@gmail.com; phone, +9779841550852 
to local economy and to formulate and design local level development and conservation strategies.

The aggregated effect of increasing global demand, rise in price and contribution to household and local income could led the MAP species towards overexploitation and may cause threats to their sustainability. Further, studies suggested that most of the MAP species traded in and from Nepal are wild harvested (Olsen 2005; Ghimire et al. 2015) and are considered as common property resource (Pandit and Thapa 2003). Most of the high-value MAPs are long-lived perennial with slow growth and show high habitat specificity (Ghimire 2008). Premature and over-harvesting by uprooting or cutting of whole plant is one of the serious concerns for the sustainability of such species (Ghimire et al. 2008; Deb et al. 2015). It has been estimated that $85 \%$ of medicinal plants of Nepal are harvested from Mid- and far-western regions of Nepal (GIZ 2011). Far-west Nepal alone contribute about one third of the total traded volume from Nepal (Kunwar et al. 2015). This paper aims to (i) quantify the trade of MAPs and identify the most commonly traded species, (ii) estimate the contribution of MAPs to household income, and (iii) assess the local conservation status of traded MAPs of Baitadi district of far-western Nepal.

\section{Materials and Methods}

\section{STUDY AREA}

The study was conducted in Baitadi district $\left(29^{\circ} 19^{\prime}\right.$ to $29^{\circ} 40^{\prime} \mathrm{N}$ and $80^{\circ} 22^{\prime}$ to $80^{\circ} 50^{\prime} \mathrm{E}$ ) of far-western Nepal (now province number 7 under new federal system). The district is bordered by Darchula in the north, Dadeldhura in the south, Bajhang and Doti in the east, and Uttarakhand state of India in the west. Baitadi district has $1,519 \mathrm{~km}^{2}$ area but considerable variation in elevation (390 to $2950 \mathrm{~m}$ asl) enables the district to have tropical to temperate climate. The area experiences a maximum temperature of $32.4^{\circ} \mathrm{C}$ and minimum of $0.5^{\circ} \mathrm{C}$, with average annual rainfall of $1242.5 \mathrm{~mm}$ (UNFCO 2013). The population of the district is 250898 with a total household of 45167 . The overall literacy rate is $63 \%$ and the human development index is 0.391 (CBS 2012).

Most of the village development committees (VDCs) of the district are accessible to road network. Three major highways of far-western Nepal pass through Baitadi district: (i) Dashrath Chand highway from Dadeldhura to Jhulaghat (89 km falls in Baitadi), (ii) Jaya Prithibi Bahadur Singh Marg (highway) from Khodpe to Chainpur, Bajhang $(29.6 \mathrm{~km}$ in Baitadi), and (iii) Baitadi-Darchula highway from Satabanjh

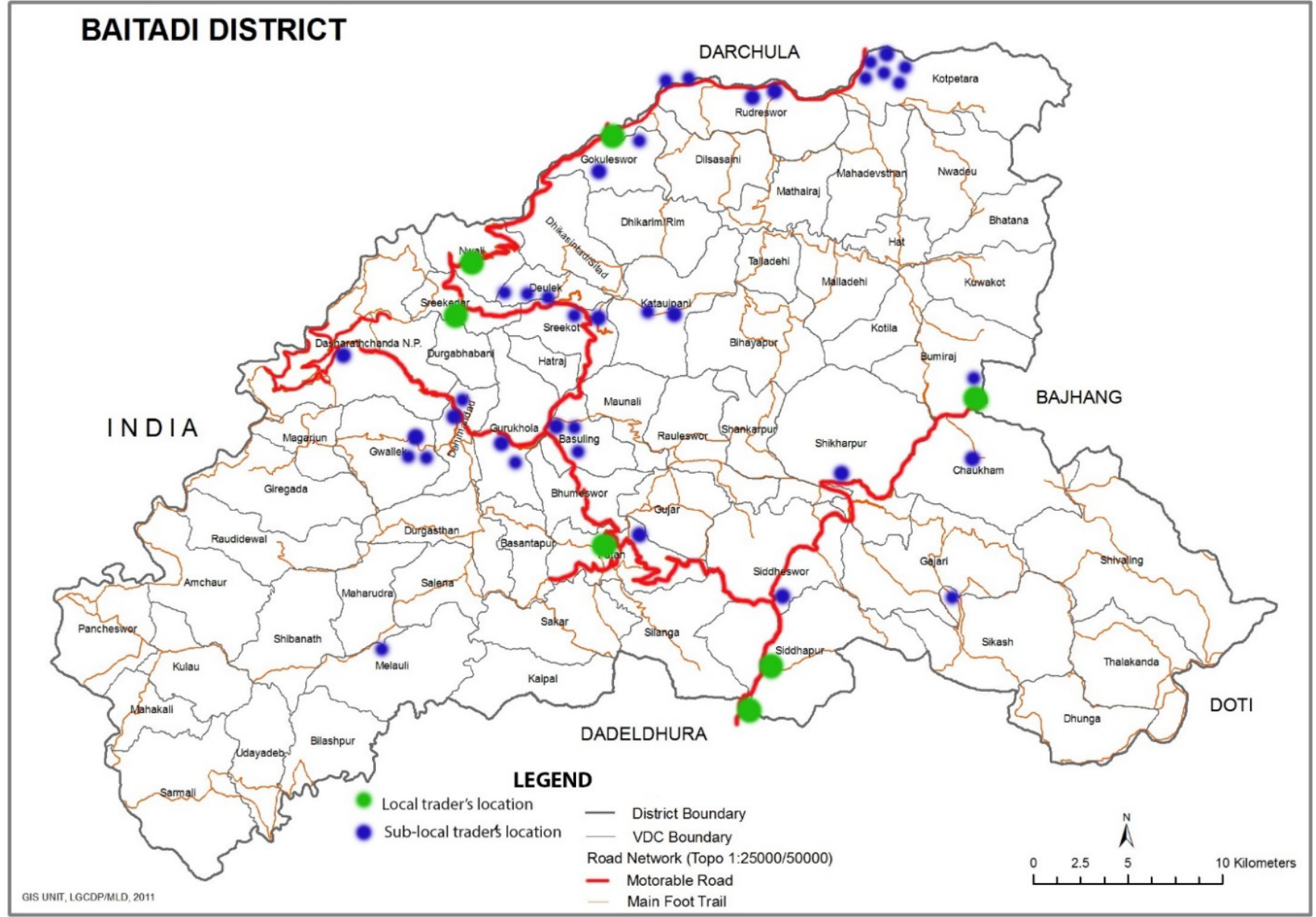

Figure 1. Study district showing the location of local and sub-local traders (map adopted from LGCDP 2014). 
to Khalanga, Darchula (53 km in Baitadi). Likewise, there are several earthen roads, viz. Gokuleshowr to Kotpetra, Patan to Pancheshwor and seasonal agricultural roads, together making up $240 \mathrm{~km}$ of extensive road network within the district (DoLIDAR 2016). Each village or hamlet has minor market centre, whereas major market centres are located at Khodpe, Patan, Dehimandu, Gothalapani, Gokuleshwor, Rudreshwor and Nwali, or along the highways (Figure 1).

Rittha (Sapindus mukorossi), kaulo (Persea odoratissima), tejpat (Cinnamomum tamala), amala (Phyllanthus emblica), pakhanved (Bergenia ciliata), chutro (Berberis spp.), sugandhawal (Valeriana jatamansi) and jiwanti (Dendrobium sp.) are the major medicinal plants harvested and traded commonly from Baitadi district (DoF 2015). Lichens were one of the major traded MAPs of Baitadi till 2011 (Kala 2003) but the trade was prohibited after Government of Nepal's decision to ban lichen for harvest, use, trade and export in early 2011 (GoN-MFSC 2011).

\section{DATA COLLECTION}

Socio-economic and trade data on MAPs for fiscal year 2014/015 (Shrawan 2071 to Ashad 2072) were collected from September to October, 2015 through interviews with harvesters and traders using pre-tested structured questionnaire. Verbal consent, from each respondent, was obtained before interview. Interviews were recorded in Samsung SM-T365 tablet using ODK collect 1.4.10 software (https://odk-collect. en.uptodown.com/android) and the data was downloaded in Microsoft excel. The interview was mainly focused on socio-economic (age and experience of respondents and total household income) and trade (number of actors in the district, traded products, including value and volume of trade, advance payments and destination of sale) information. We quantitatively interviewed 24 harvesters, 35 sub-local traders and 7 local traders. We used Olsen and Bhattarai (2005) typology to describe the actors. Harvesters harvest MAPs either from wild or from cultivation and sell to sub-local traders who generally operates from villages. Sub-local traders sell to local traders who operates from district headquarters and major market centres. Local traders transport MAPs out of the district and sell to central wholesalers who mostly reside in Tarai cities or in Kathmandu and finally export to regional wholesalers in India, China and other countries.

The number of harvesters interviewed was less as they were meant to validate the price mentioned by sub-local and local traders. We interviewed the entire population of local traders because we were interested in quantifying the value and volume of trade from the district, and it was local traders who transport MAPs out of the district. Care was taken not to record the products harvested from adjoining districts. We used the information of central wholesalers ( $n=35$, purchasing
MAPs from Baitadi district) to estimate the advance payments and trade destination.

Samples and photographs of traded product were taken, and confused species were taxonomically identified at national herbarium (KATH) in Godawari, Kathmandu. Catalogue of life (Hassler 2017) was referred to validate the scientific name with author citation.

We used rapid vulnerability assessment (RVA) method developed by Cunningham (1996) and adopted by other researchers in Nepal (Ghimire and Aumeeruddy-Thomas 2005; Shrestha and Shrestha 2012) to identify the vulnerability of traded MAPs of the district. However, we excluded all mushrooms and lichen from the analysis due to unavailability of sufficient data on habitat, population size and elevation ranges within Nepal. Similarly, Dendrobium sp. was also excluded. Thus we used 13 species traded from the district and 10 predictors of vulnerability with score ranging from 1 to 4 : 1 being lowest and 4 being highest vulnerability (Annex 1). Transect walk and empirical observations, interviews and literature were the basis for scoring the vulnerability. Empirical observations and interview gave information on life form, parts used, unit price, trade volume, and habitat specificity and local population size. Likewise, published literature (Polunin and Stainton 1984; Press et al. 2000; Watson et al. 2011) and online databases (IUCN 2017; Hassler 2017) were referred for global distribution, nativity, habitat specificity, altitudinal span and conservation status.

\section{DATA ANALYSIS}

Traded volumes of sub-local and local traders were treated separately to avoid duplication. MAPs that were traded within same actor level (e.g., within local traders) were carefully treaded to avoid double counting. Likewise, MAPs that were still in the stock (i.e., not sold due to various reasons) was also deducted for exact quantification of trade from the district. Person correlation coefficients were calculated between age and experience of harvesters, sub-local and local traders. Person correlations and other basic statistics were performed using Stata 12.1 (StataCorp 2011).

\section{Results}

\section{CHARACTERISTICS OF HARVESTERS AND TRADERS}

In Baitadi district, 6875 households (15.2\%) were engaged in harvesting of medicinal plants for trade (traders' reference). There was a positive correlation $(r=0.463 ; p<0.001)$ between age (mean $39.2 \mathrm{y}$ ) and experience (7.9 y) of harvesters. Both male and female household members were engaged in harvesting. Harvesters, in average, harvest two MAP species. Almost $50 \%$ harvesters considered themselves to have average wealth. The average household income of harvesters was NRs 135625 (US\$ 1365.8; using the mean conversion rate 
Table 1. Characteristics of harvesters $(n=24)$. Data shown are minimum, maximum and average value of socio-economic characteristics*.

\begin{tabular}{lllll} 
Characteristics & Min & Max & Average & SD \\
\hline Age (year) & 15 & 67 & 39.2 & 15.7 \\
Experience in harvest (year) & 3 & 40 & 7.9 & 7.1 \\
Total cash income (NRs) & 20000 & 350000 & 135625.0 & 68339.1 \\
Cash income from MAPs (NRs, \%) & $500(<1 \%)$ & $43600(43.6 \%)$ & $12882.0(9.5 \%)$ & 11265.0 \\
Products harvested in average (no.) & 1 & 4 & 2.1 & 0.3 \\
\hline
\end{tabular}

*Min - minimum, Max - maximum, SD - standard deviation.

Table 2. Characteristics of sub-local $(n=35)$ and local $(n=7)$ traders*.

\begin{tabular}{lllllllll}
\hline \multirow{2}{*}{ Characteristics } & \multicolumn{3}{c}{ Sub-local trader } & \multicolumn{4}{c}{ Local trader } \\
\cline { 2 - 9 } & Min & Max & Mean & SD & Min & Max & Mean & SD \\
\hline Age (year) & 20 & 62 & 41.1 & 11.5 & 27 & 50 & 39.0 & 8.7 \\
Experience in trade (year) & 2 & 15 & 7.3 & 3.6 & 2 & 20 & 11.5 & 6.1 \\
Share of MAPs to total income (\%) & 1 & 100 & 19.4 & 21.0 & 25 & 100 & 67.1 & 22.7 \\
Advance paid by (\%) & 0 & 50 & 2.3 & 5.1 & 0 & 50 & 32.2 & 13.0 \\
Number of products traded in average & 1 & 8 & 2.8 & 1.8 & 2 & 12 & 8.7 & 4.3 \\
MAPs storage time (months) & 1 & 7 & 2.7 & 1.3 & 2 & 5 & 4.1 & 1.1 \\
No of harvesters sold to & 40 & 500 & 150 & 98.6 & 70 & 500 & 231 & 159.4 \\
\hline
\end{tabular}

*Min - minimum, Max - maximum, SD - standard deviation.

of US\$ 1 = NRs 99.3 in 2014/015). Contribution of MAPs to total cash income was $9.5 \%$, that ranged from less than $1 \%$ to $43.6 \%$ (Table 1 ) thereby providing a supplementary source of income for harvesters.

Positive correlation existed between age (mean $41.1 \mathrm{y}$ ) and experience (7.3 y) of sub-local traders $(r=0.575 ; p<0.001)$, as well as between age ( $39 \mathrm{y})$ and experience (11.5 y) of local traders $(r=0.742 ; p<0.001)$. Almost $19.5 \%$ (in the case of sublocal traders) and $67 \%$ (local traders) of their income come from MAPs trade (Table 2). Sub-local traders traded three MAP products in average, the major being rittha (Sapindus mukorossi), tejpat (Cinnamomum tamala) and pakhanved (Bergenia ciliata), whereas local traders, in average, traded nine products. Sub-local and local traders in an average purchased MAPs respectively from 150 and 231 harvesters (Table 2). But local traders in most of the cases purchased from sub-local traders.

\section{TRADE SYSTEM}

Harvesters collect the wild crafted $(n=12)$ and cultivated $(n=$ 5) MAP species (Table 3 ) and perform primary processing, like cleansing, drying and packaging. The products were then sold to sub-local traders at minor markets or to local traders at major market centres. Generally, harvesters receive advance in kind (foodstuffs and clothing) from sub-local traders throughout the year therefore they receive very little cash advance (less than $3 \%$ ) (Table 2). Sub-local traders often have mutual business relationship with harvesters of a specific location. Sub-local traders keep on purchasing MAPs till the volume is enough for a tractor/truck load (depending upon road condition). Sub-local traders store MAPs for little more than two and half months. They receive $32 \%$ advance payment in cash from local traders (Table 2). Once the volume is fulfilled, local traders transport MAPs from minor markets to their warehouse located at major market centres. There were no any local traders in the district headquarters, the possible reason could be the location. The district headquarters is $18.5 \mathrm{~km}$ west to the highway and cost of transportation would be high, along with multiple loads and unloads. The usual time of storage was four and half months for local traders after which the products were finally transported to Nepalgunj, Mahendranagar and Kathmandu for export and domestic consumption (Table 3). Local traders received 22\% advance from central wholesalers.

\section{VOLUME AND VALUE OF TRADE}

We used local traders' data to quantify the value and volume of trade from the district. Total volume of trade was 731.5 tons, from 17 products constituting 17 species (Table 3). Sapindus mukorossi was traded in highest volume (356.5 tons), followed by Cinnamomum tamala (Tejpat, 171 tons) and Bergenia ciliata (70.1 tons). The top five and top 10 products respectively contributed to $93.8 \%$ and $99.2 \%$ of total traded volume. The trade also constituted government banned lichens, but the trade was in minimal quantity. Furthermore, only sub-local traders mentioned the trade of lichen. Local traders rarely disclosed the unofficial trade as they were aware about the legal provisions.

The cumulative value of trade was NRs 31.3 million (US\$ 315,175). The cumulative value of trade was highest for satuwa (Paris polyphylla) with NRs 7.7 million, followed by 
Cinnamomum tamala (tejpat, NRs 6.4 million) and Sapindus mukorossi (NRs 5.3 million). The top five products contributed to $76.4 \%$ of the total trade value, whereas the top 10 products made up 95.3\%. Guchi chyau (Morchella esculenta) was the most expensive MAP (NRs 12000 per kilogram) harvested and traded from the district, but the production was very low.

More than $82 \%$ of traded volume of MAPs harvested from Baitadi were exported to India via Nepalgunj, a city located at the mid-western Tarai of Nepal, making this the most preferred 'transit' city, followed by Mahendranagar (far-western Tarai) and Kathmandu (the capital city, Table 3). Species, like Paris polyphylla and Dendrobium sp. were exported to various cities of China via Kathmandu, these were mostly airlifted. It has not been long since the trade of Ganoderma lucidum has commenced in Nepal. Two local traders from Siddheshwor VDC disclosed the trade of Ganoderma lucidum to China via Kathmandu. The most remarkable was the transport of 95 tons of Sapindus mukorossi to Kathmandu (Table 3). India was the major destination of Sapindus mukorossi for several years and transporting Sapindus mukorossi to Kathmandu signifies that whether it was being domestically processed, or export to other countries via Kathmandu, the actual reason remained unknown.

\section{VULNERABILITY}

Out of 17 traded species, seven were listed in conservation/ protection categories (Table 4). Acorus calamus has been listed as least concern in IUCN red list. Swertia chirayita has been listed as vulnerable in IUCN and CAMP (Conservation Assessment Management Plan) list. Though bulk of the supply of Swertia chirayita are sourced from cultivation, especially from eastern Nepal, there are no reports of mass scale cultivation in the west. Asparagus racemosus and Paris polyphylla are vulnerable in CAMP list. All wild orchids (including Dendrobium sp.) are in CITES appendix II. Raw export of Valeriana jatamansi is banned by the Government of Nepal but valerian oil and marc (residue after extraction of essential oil) obtained from distillation can be exported. We

Table 3. MAPs traded from Baitadi district in FY 2014/015.

\begin{tabular}{|c|c|c|c|c|c|}
\hline Scientific name (family) & Trade name & $\begin{array}{c}\text { Volume } \\
\text { traded } \\
\text { (kg) }\end{array}$ & $\begin{array}{c}\text { Rate } \\
\text { (NRs/ } \\
\text { kg) }\end{array}$ & $\begin{array}{l}\text { Amount } \\
\text { (NRs) }\end{array}$ & 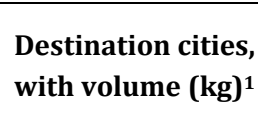 \\
\hline Acorus calamus L. (Acoraceae) & Bojho & 4,150 & 60.75 & 252,113 & NEP \\
\hline Asparagus racemosus Willd. (Asparagaceae) & Kurilo & 1,000 & 50 & 50,000 & MAH \\
\hline $\begin{array}{l}\text { Berberis aristata DC. (Berberidaceae) } \\
\text { Berberis asiatica Roxb. ex DC. (Berberidaceae) }\end{array}$ & Chutro & 11900 & 29 & 345100 & $\begin{array}{l}\text { NEP (8900), MAH } \\
(3000)\end{array}$ \\
\hline Bergenia ciliata (Haw.) Sternb. (Saxifragaceae) & $\begin{array}{l}\text { Bhiniti, } \\
\text { Pakhanved }\end{array}$ & 70,100 & 25.6 & $1,794,560$ & NEP \\
\hline Cinnamomum tamala (Buch.-Ham.) Th. G.G. Nees & Tejpat & 171,000 & 37.16 & $6,354,360$ & NEP \\
\hline (Lauraceae) & Dalchini & 15,550 & 68.25 & $1,061,288$ & $\begin{array}{l}\text { NEP (14550), MAH } \\
(1000)\end{array}$ \\
\hline Dendrobium sp. (Orchidaceae) & Jiwanti & 745 & 350 & 260,750 & KTM \\
\hline $\begin{array}{l}\text { Everniastrum nepalense (Taylor) Hale ex Sipman } \\
\text { (Parmeliaceae) }\end{array}$ & Jhyau & 400 & 50 & 20,000 & BHA \\
\hline Ganoderma lucidum (Curtis) P. Karst. (Ganodermataceae) & Livlite chyau & 420 & 3925 & $1,648,500$ & $\begin{array}{l}\text { NEP (220), KTM } \\
(200)\end{array}$ \\
\hline Machilus odoratissima Nees (Lauraceae) & Kaulo & 39,500 & 46.6 & $1,840,700$ & $\begin{array}{l}\text { NEP (28500), MAH } \\
(11000)\end{array}$ \\
\hline Morchella esculenta (L.) Pers. (Morchellaceae) & Guchi chyau & 25 & 12000 & 300,000 & KTM \\
\hline Paris polyphylla Sm. (Melanthiaceae) & Satuwa & 2,085 & 3700 & $7,714,500$ & KTM \\
\hline Phyllanthus emblica L. (Phyllanthaceae) & Amala & 49,500 & 55.6 & $2,752,200$ & NEP \\
\hline Sapindus mukorossi Gaertn. (Sapindaceae) & Rittha & 356,500 & 14.75 & $5,258,375$ & $\begin{array}{l}\text { NEP (251500), KTM } \\
(95000), \mathrm{MAH} \\
(10000)\end{array}$ \\
\hline Valeriana jatamansi Jones (Caprifoliaceae) & $\begin{array}{l}\text { Samayo, } \\
\text { Sugandhawal }\end{array}$ & 5,450 & 163.3 & 889,985 & $\begin{array}{l}\text { NEP (3950), MAH } \\
(1500)\end{array}$ \\
\hline Zanthoxylum armatum DC. (Rutaceae) & Timur & 1,000 & 250 & 250,000 & NEP \\
\hline
\end{tabular}

${ }^{1}$ KTM - Kathmandu; NEP - Nepalgunj; MAH - Mahendranagar; BHA- Bhairahawa. 


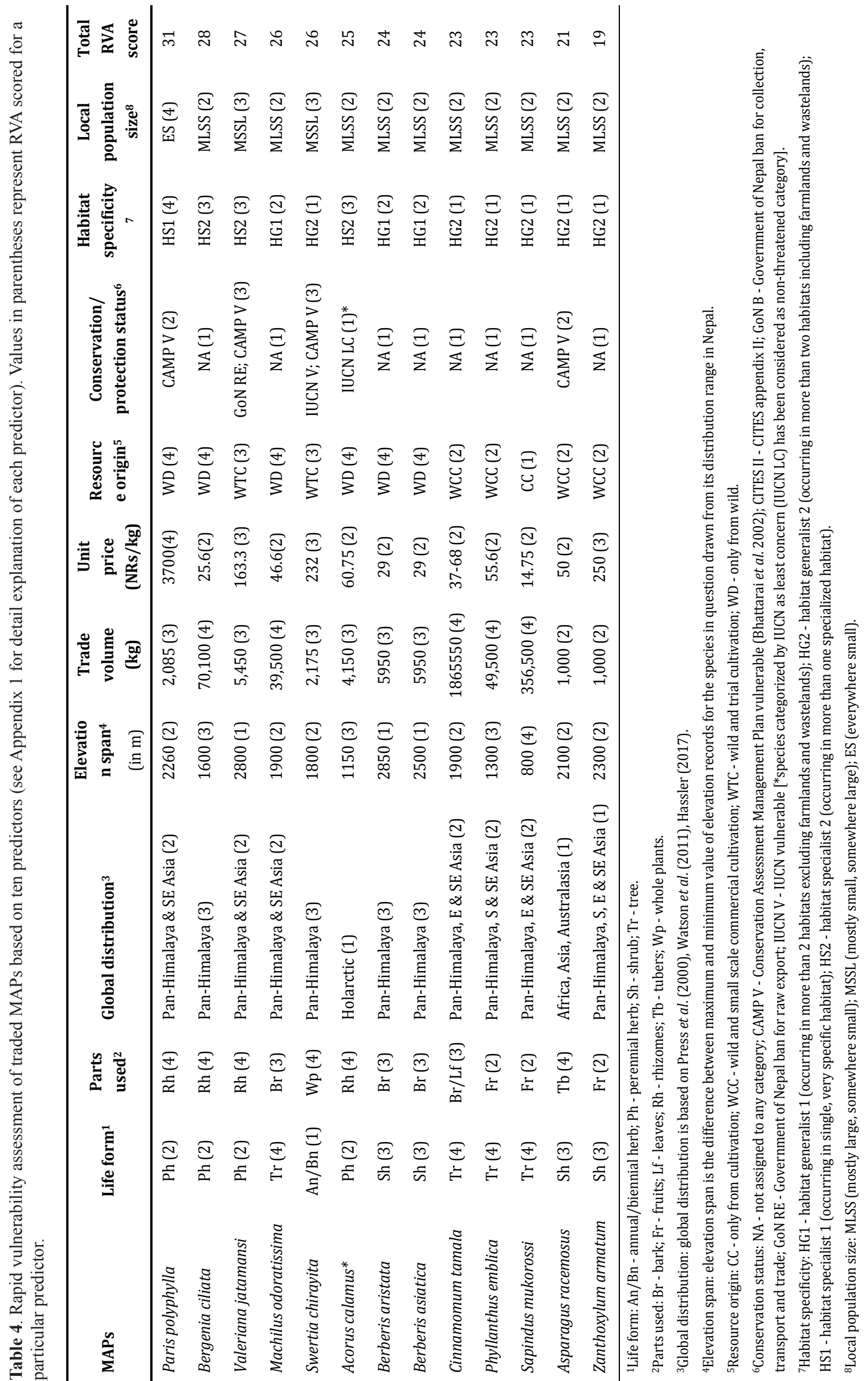


also recorded the trade of $400 \mathrm{~kg}$ of government banned lichen (Everniastrum nepalensis) from the district.

We conducted RVA of 13 traded MAP species of Baitadi (excluding 2 species of mushrooms, 1 species of lichen and 1 species of Dendrobium) using 10 predictors (Appendix 1, Table 4). Paris polyphylla was identified as the most vulnerable species with vulnerability score of 31 (Table 4). There were several reasons for the high vulnerability of this species, but the major ones were (i) destructive harvesting of rhizomes, (ii) high market price, (iii) high habitat specificity (growing in forests with thick crown cover and moist places), and (iv) harvesting only from wild source. More than 2 tons of Paris polyphylla with average unit price of NRs 3700 per kg were harvested from wild source in the district (Table 3). Two, out of seven, local traders purchased Paris polyphylla and both perceived the declining population due to premature and over harvesting. Usually, harvesting of Paris polyphylla should be done after flowering and seed dispersal during October, but it was prematurely harvested due to high price and escalating demand in the region, leading to its declining status in the wild.

Other vulnerable species were Bergenia ciliata and Valeriana jatamansi with vulnerability score of 28 and 27 , respectively; and Machilus odoratissima and Swertia chirayita each with the score of 26 . The least vulnerable species was Zanthoxylum armatum with the score of 19. The top eight species in the vulnerable list (Table 4) were mostly harvested from wild, showing that MAPs harvested from wild without adopting any cultivation practice are always at high risk.

\section{Discussion}

\section{ECONOMIC CONTRIBUTION AND TRADE}

More than 15\% households of Baitadi district were engaged in commercial harvesting of MAPs contributing to $9.5 \%$ of the total annual household income. Our findings on economic contribution was slightly lower than previous studies: Bista and Webb (2006) estimated $11.7 \%$ contribution from NTFPs in Baitadi; Kunwar et al. (2013) estimated 20\% income from sale of MAPs in Darchula, Baitadi and Dadeldhura; and Olsen and Larsen (2003) estimated 12\% contribution of MAPs in higher elevations in Nepal. The contribution of MAPs to the overall income was low because of two main reasons: (i) rather than going for commercial cultivation, communities are adopting small-scale domestication practice by planting few trees (e.g., Sapindus mukorossi and Cinnamomum tamala) in the backyards or in the edges of agricultural fields providing them with alternative source of income, and (ii) low unit price of traded MAPs of Baitadi with average per unit price of NRs $35.9 / \mathrm{kg}$ for top five products that make about $94 \%$ of traded volume. But even with the lower price, households are harvesting MAPs for trade because of the extensive road network in Baitadi that reduces the transportation cost and enables low valued MAPs to find the market. It indicates that though MAPs comprise only a portion of household income, it helps to stabilize household economics by providing supplementary role to the harvesters, as observed by Godoy et al. (2000) in the rain forest of Honduras.

Our study quantified the trade of 731.5 tons of MAPs comprising 17 products from Baitadi district in FY 2014/15. Our finding was quite similar to the quantification made by Kala (2003) who mentioned the export of 755 tons (from 16 MAP products) from Baitadi to Pithoragarh (India) for case year 2002. Sapindus mukorossi, Cinnamomum tamala, Bergenia ciliata and Phyllanthus emblica were traded in highest quantities in both case years. Among other products, Kala (2003) mentioned the export of 40 tons of lichens, 15 tons of kutki (Neopicrorhiza scrophulariiflora) and 10 tons of jatamansi (Nardostachys jatamansi). Trade of lichen was legal in 2002, whereas kutki and jatamansi were not found in Baitadi, rather sourced from Darchula. It showed that quantification made by Kala (2003) is overstated by MAPs of Darchula and the trade volume of MAPs sourced specifically from Baitadi district was increased (after deducting the trade volume of lichens, kutki and jatamansi), mostly because of the extensive road network, as stated earlier. There are other studies (ANSAB 2003; Bista and Webb 2006; Kunwar et al. 2013) that lists higher number of traded MAPs (range: 22-38 MAPs products) from the district but they lacked quantification. However, the major traded species were similar in all studies.

We recorded the trade of live-lite chyau (Ganoderma lucidum) from Baitadi which was not recorded earlier. At the same time, majitho (Rubia manjith), halhale (Rumex nepalensis) and kakadsinghi (Pistacia chinensis subsp. integerrima) which were reported previously (e.g., by Kala 2003) were not documented in our study. The appearance and disappearance of MAPs signifies the dynamic nature of trade, probably due new market preferences and declining population of MAPs, but the exact reason is inadequately known.

Till 2002, MAPs of Baitadi and Darchula were exported to India via Julaghat (a small Indian border city west to Jhulaghat of Baitadi, Nepal) but increased political instability in Nepal caused the closure of Indo-Nepal border of Baitadi in 2003 (Bista and Webb 2006). Since then, MAPs of Baitadi and rest of the far-western Nepal are exported to India and China via Nepalese 'transit cities' of Nepalgunj, Mahendranagar and Kathmandu. Nepalgunj has the long history of trading MAPs that dates to centuries. The number of traders and central wholesalers were very high in Nepalgunj in the past because of absence of any regulatory mechanism in the border. Though the import policy of Uttar Pradesh State, Government of India (requirement of transit permit for export to India) dramatically reduced the number of central wholesalers $(n=12)$, significant 
volume was still traded from Nepalgunj. For example, Jadibuti Association of Nepal (JABAN) issues the recommendation letter to District Forest Office, Banke (Nepalgunj) for MAPs export and they have recommended to export 4596 tons of MAPs in FY 2014/015 (JABAN 2015), demonstrating that Nepalgunj is still the most favored transit city in Nepal in terms of MAPs export to India. Fourteen out of 17 MAPs were exported to India and only three (Ganoderma lucidum, Paris polyphylla and Dendrobium sp.) were exported to China via Kathmandu.

\section{CONSERVATION}

Eleven MAP products from 12 species were wild harvested from community forests or government managed forests. MAPs found in those forest management regimes are considered common property resource and receive intense harvest pressure. However, all MAPs found in a specific area are not equally affected by harvesting pressure (Schippmann et al. 2005) as impact of harvest and postharvest recovery is largely determined by availability, market demand, parts harvested and biology/ecology of MAP population (Ghimire et al. 2008). Sapindus mukorossi, Cinnamomum tamala, Bergenia ciliata, Phyllanthus emblica, Machilus odoratissima and Paris polyphylla contributed $94.1 \%$ of volume and $82.2 \%$ of cumulative value of trade from the district, demonstrating high harvest pressure on these MAPs. High market demand of specific MAPs may lead to unsustainable harvesting thereby threatening their survival in wild and affecting the people who depend on these resources.

Fruits of Sapindus mukorossi and Phyllanthus emblica and leaf of Cinnamomum tamala are traded. Harvesting of these plant parts are considered less destructive because they do not directly contribute for reproduction, but intensive harvest of these parts may indirectly affect the reproductive performance (Gaoue and Ticktin 2007). Harvesting of MAPs other than these are considered destructive as removal of roots, bark or whole plants lead to death of plant (Cunningham 1993). Further, species with high economic importance are at risk of overexploitation (Hamilton 2004). Morchella esculenta, Ganoderma lucidum and Paris polyphylla thus are at high risk of overexploitation because of their relatively high trade value. Harvesting of Morchella esculenta and Ganoderma lucidum involves removal of whole individual and harvesting of Paris polyphylla involves the removal of plant and collection of rhizome.

The trade of government banned lichen operates in a small scale using the informal routes, often camouflaged as other products. As per a sub-local trader (ID 100) "we know that lichens are banned for export, but I am purchasing from harvesters, means that there may be more traders who are engaged in trade of lichens". His statement was true as a sub-local trader (ID 149) purchased lichen but did not want to disclose the volume. It gives an indication that ban did not work for products that have market demand, rather other regulatory mechanisms (e.g., rotational harvesting, short-term harvest ban in specific areas) should be explored that ensures the sustainability and secure the income for harvesters.

Satuwa (Paris polyphylla) was identified as the most vulnerable MAP species of the district and it alone shared $24.6 \%$ contribution of cumulative trade value. The price of Paris polyphylla increased from NRs 700 per kg in January 2010 (ANSAB 2010) to NRs 3700 per kg in August 2014. This multi-fold increase in price tempted harvesters for premature and over-harvesting from wild. According to a local trader (ID 151) "all satuwa traded in and from Baitadi were harvested wild from Shikharpur and Chaukham VDCs as cultivation of satuwa is not initiated till date", thereby causing threat to the long-term viability of its populations. The decreasing population of Paris polyphylla in wild was well described by another local trader (ID 153) " premature harvesting of MAPS is a major concern. October is the right month for collection, but people start harvesting from August. Five years ago, I used to purchase 40-50 tons of satuwa from Baitadi and Darchula but now I hardly manage to purchase 1-1.5 tons in a year. If situation remains same, I may not be able to purchase satuwa in near future". The statement indicates the prevailing threat and need of robust plan for MAP conservation. Study by KC et al. (2010) reported the unsustainable harvesting of Paris polyphylla even though it was harvested only for domestic use in Ghandruk, central Nepal. It was even more surprising that Paris polyphylla is not in the conservation list of GoN, CITES Appendix and IUCN red list (www.iucnredlist.org, accessed 13 Dec 2017) despite reports of declining population in the Himalayan region due to the high market demand leading to overexploitation and undocumented trade (Paul et al. 2015). The biggest setback to assign the conservation categories may be the unknown population size across the habitat range. Limited global distribution, slow growth rate, habitat degradation, exceptionally high demand and destructive harvesting practice are the major reasons to include Paris polyphylla in the global protection list. With these identified threats, a thorough bio-physical study is needed that provides strong basis for Nepal to keep Paris polyphylla in any of the national conservation categories.

\section{Conclusions}

Nepalese MAPs have been traded for centuries and the demand will continue to rise because of global expansion of herbal market. Nepal must grab this opportunity by initiating commercial cultivation of native traded species (like Sapindus mukorossi, Cinnamomum tamala, Zanthoxylum armatum) 
which have established market. Enhanced transportation facilities in the mid-hilly regions makes it ideal place for commercial level cultivation, whereas harvest can be regulated for high-value wild MAPs which are often found in higher elevations. But imposing strict regulation (like ban) seems less effective because species with high trade value are traded one way or another. Therefore, rather than going for strict regulatory mechanism, government must adopt sustainable use and management approach. Though income from MAPs comprise $9.5 \%$ of total household income, the trade can help to stabilize the household economics by providing supplementary income. More than $93 \%$ of the traded volume is occupied by five MAP species, showing their dominancy in trade in one hand and high harvest pressure on the other. Most of the low-value MAPs are still exported to India, whereas few high-value MAPs are exported to China. The study identifies Paris polyphylla as the most vulnerable MAP of the district mainly because of large scale collection which may have negative effects on its population given the species biology. Thus, Government of Nepal should conduct integrated trade and bio-physical studies that provides concrete foundation to assign the conservation status for Paris polyphylla.

\section{Acknowledgements}

The authors would like to acknowledge Prof. Dr. Carsten Smith-Hall for guidance and constructive suggestions, Dr. Mariève Pouliot for data management, Mr. Krishna Thagunna and Subash Chand for field support and harvesters, traders and wholesalers for their time and providing the information. The study was financed by the Research Committee for Development Research (FFU) of the Danish Ministry of Foreign Affairs, Grant No. 13-07KU.

\section{References}

Angelsen A., Jagger P., Babigumira R., Belcher B., Hogarth N., Bauch S., Börner B., Smith-Hall C. and Wunder S. 2014. Environmental income and rural livelihoods: a global-comparative analysis. World Development, 64: S12-S28.

ANSAB 2003. Market Assessment of Non-Timber Forest Products in Darchula and Baitadi Districts, Far-west Nepal. Asia Network for Sustainable Agriculture and Bioresources, Kathmandu, Nepal.

ANSAB 2010. Price Lists. [online] URL: http://www.ansab.org/ market-information/price-lists/ (assessed 15 Oct 2013).

Bhattarai K.R. and Ghimire M. 2006. Commercially important medicinal and aromatic plants of Nepal and their distribution pattern and conservation measure along the elevation gradient of the Himalayas. Banko Jankari, 16(1): 3-13.

Bhattarai N., Tandon V. and Ved D.K. 2002. Highlights and outcomes of the Conservation Assessment and Management Planning (CAMP) Workshop, Pokhara, Nepal. In: Sharing Local and National Experience in Conservation of Medicinal and Aromatic Plants in South Asia (N. Bhattarai and M. Karki, eds.), pp. 46-53. IDRC, New Delhi, India.
Bista S. and Webb E.L. 2006. Collection and marketing of non-timber forest products in the Far Western Hills of Nepal. Environmental Conservation, 33(3): 244-255.

CBS 2012. National Population and Housing Census. National Planning Commission, Kathmandu, Nepal.

Cunningham A.B. 1993. African Medicinal Plants: Setting Priorities at the Interface Between Conservation and Primary Healthcare. People and Plant Working Paper 1, UNESCO, Paris, France.

Cunningham A.B. 1996. Working towards a "Top 50" listing. Medicinal Plants Conservation, 2: 4-6.

Deb C.R., Jamir S.L. and Jamir N.S. 2015. Studies on vegetative and reproductive ecology of Paris polyphylla Smith: a vulnerable medicinal plant. American Journal of Plant Sciences, 6: 2561-2568.

DoF 2015. Hamro Ban. Department of Forests, Ministry of Forests and Soil Conservation, Government of Nepal, Kathmandu, Nepal.

DoLIDAR 2016. Statistics of Local Road Network (SLRN) 2016. Government of Nepal, Ministry of Federal Affairs and Local Development, Department of Local Infrastructure Development and Agricultural Roads.

Edwards D.M. 1996. Non-timber Forest Products from Nepal; Aspects of the Trade in Medicinal and Aromatic Plants. FORESC Monograph 1/96, Forest Research and Survey Centre, Ministry of Forests and Soil Conservation, Kathmandu, Nepal.

Farnsworth N.R. and Soejarto D.D. 1991. Global importance of medicinal plants. In: Conservation of Medicinal Plants (O. Akerele, V. Heywood and H. Synge, eds.), pp 25-51. Cambridge University Press.

Gaoue O.G. and Ticktin T. 2007. Impacts of bark and foliage harvest on Khaya senegalensis (Meliaceae) reproductive performance in Benin. Journal of Applied Ecology, 45: 34-40.

Ghimire S.K. 2008. Sustainable harvesting and management of medicinal plants in the Nepal Himalaya: current issues, sustainable harvesting, knowledge gaps and research priorities. In: Medicinal Plants in Nepal: An Anthology of Contemporary Research (P.K. Jha, S.B. Karmacharya, M.K. Chhetri, C.B. Thapa and B.B. Shrestha, eds.), pp. 25-42. Ecological Society (ECOS), Kathmandu, Nepal.

Ghimire S.K. and Aumeeruddy-Thomas Y. 2005. Approach to in-situ conservation of threatened Himalayan medicinal plants: a case study from Shey Phoksundo National Park, Dolpa. In: Himalayan Medicinal and Aromatic Plants: Balancing Use and Conservation (Y. Aumeeruddy-Thomas, M. Karki, D. Parajuli, and K. Gurung, eds.), pp 209-234. WWF-UNESCO, People and Plant Initiative/ WWF Nepal/IDRC, Kathmandu, Nepal.

Ghimire S.K., Awasthi B., Rana S., Rana H. and Bhattarai R. 2015. Status of Exportable, Rare and Endangered Medicinal and Aromatic Plants (MAPS) of Nepal. Report submitted to Department of Plant Resources (DPR), Ministry of Forest and Soil Conservation (MoFSC), Kathmandu, Nepal.

Ghimire S.K., Gimenez O., Pradel R., McKey D. and AumeeruddyThomas Y. 2008. Demographic variation and population viability in a threatened medicinal and aromatic herb (Nardostachys grandiflora): effects of harvesting in two contrasting habitats. Journal of Applied Ecology, 45: 41-51.

GIZ 2011. Medicinal and Aromatic Plants: Poverty Impact Assessment of Proposed Trade Support Measures in Nepal's MAPs Sector. GIZ, Kathmandu, Nepal. 
Godoy R., Wilkie D., Overman H., Cubas A., Cubas G., Demmer J., Mcsweeney K. and Brokaw N. 2000. Valuation of consumption and sale of forest goods from a central American rain forest. Nature, 406: 62-63.

GoN-MFSC 2011. Nepal Gazette 60 (no 38). Government of Nepal, Ministry of Forests and Soil Conservation.

Hamilton A.C. 2004. Medicinal plants, conservation and livelihoods. Biodiversity and Conservation, 13: 1477-1517.

Hassler M. 2017. World Plants: Synonymic Checklists of the Vascular Plants of the World. Version Nov. 2017. In: Species 2000 and ITIS Catalogue of Life, 30th Nov. 2017 (Roskov Y., Abucay L., Orrell T., Nicolson D., Bailly N., Kirk P.M., Bourgoin T., DeWalt R.E., Decock W., De Wever A., Nieukerken E. van, Zarucchi J., Penev L., eds.). Digital resource at www.catalogueoflife.org/col. Species 2000: Naturalis, Leiden, the Netherlands. ISSN 2405-8858.

Hertog W.H. and Wiersum K.F. 2000. Timur (Zanthoxylum armatum) production in Nepal: dynamics in non-timber forest resource management. Mountain Research and Development, 20: 135-145.

Humagain K. and Shrestha K.K. 2009. Medicinal plants in Rasuwa district, central Nepal: trade and livelihood. Botanica Orientalis, 6: 39-46.

IUCN 2017. The IUCN Red List of Threatened Species. Version 2017-1. <http://www.iucnredlist.org>. Downloaded on Nov 2018.

JABAN 2015. Official export data for FY 2017/072 (2015/015). Jadibuti Association of Nepal, Nepalgunj, Nepal

Kala C.P. 2003. Commercial exploitation and conservation status of high value medicinal plants across the borderline of India and Nepal in Pithoragarh. Indian Forester, 129: 80-84.

KC M., Phoboo S. and Jha P.K. 2010. Ecological study of Paris polyphylla Sm. Ecoprint, 17: 87-93.

Koirala P.N., Pyakurel D. and Gurung K. 2010. Orchids in Rolpa District of western Nepal: documentation, stock, trade and conservation. Banko Jankari, 20(2): 3-13.

Kunwar R.M., Acharya R.P., Chowdhary C. and Bussmann R.W. 2015. Medicinal plant dynamics in indigenous medicines in far-west Nepal. Journal of Ethnopharmacology, 163: 210-219.

Kunwar R.M., Mahat L., Acharya R.P. and Bussmann R.W. 2013. Medicinal plants, traditional medicine, markets and management in far-west Nepal. Journal of Ethnobiology and Ethnomedicine 9: 24 [online] URL: http://www.ethnobiomed.com/content/9/1/24.

LGCDP 2014. GIS District Map. Local Governance and Community Development Programme, Ministry of Federal Affairs and Local Development, Government of Nepal. [online] URL: http://gcdp. gov.np/sites/default/files/GIS/74_Baitadi.jpg.

Malla S.B., Shakya S.R. 1999. Medicinal plants. In: Nepal Natures' Paradise (T.C. Majupuria, ed.), pp. 261-297. M. Devi, Gwalior, India.

Maraseni T.N., Shivakoti G.P. Cockfield G. and Apan A. 2006. Nepalese non-timber forest products: an analysis of the equitability of profit distribution across a supply Chain to India. Small-scale Forest Economics, Management and Policy, 5: 191-206.

Olsen C.S. 1998. The trade in medicinal and aromatic plants from Central Nepal to Northern India. Economic Botany, 52: 279-292.

Olsen C.S. 2005. Valuation of commercial central Himalayan medicinal plants. Ambio, 34: 607-610.
Olsen C.S. and Bhattarai N. 2005. A typology of economic agents in the Himalayan plant trade. Mountain Research and Development, 25: $37-43$.

Olsen C.S. and Larsen H.O. 2003. Alpine medicinal plant trade and Himalayan mountain livelihood strategies. Geographical Journal 169: 243-254.

Pandit B.H. and Thapa G.B. 2003. A tragedy of non-timber forest resources in the mountain commons of Nepal. Environmental Conservation, 30: 283-292.

Paul A., Gajurel P.R. and Das A.K. 2015. Threats and conservation of Paris polyphylla an endangered, highly exploited medicinal plant in the Indian Himalayan Region. Biodiversitas, 16: 295-302.

Polunin O. and Stainton A. 1984. Flowers of the Himalaya. Oxford University Press, New Delhi.

Press J. R., Shrestha K.K., Sutton D.A., 2000. Annotated Checklist of the Flowering Plants of Nepal. The Natural History Museum, London.

Ruiz Pérez M. and Byron N. 1999. A methodology to analyse divergent case studies of non-timber forest products and their development potential. Forest Science, 45: 1-14.

Schippmann U., Leaman D.J., Cunningham A.B. and Walter S. 2005. Impact of cultivation and collection on the conservation of medicinal plants: global trends and issues. Acta Horticulturae, 676: 31-44.

Shackleton C.M. and Shackleton S.E. 2004. The importance of nontimber forest products in rural livelihood security and as safety nets: a review of evidence from South African. South African Journal of Science, 100: 658-664.

Shackleton S., Delang C.O. and Angelsen A. 2011. From subsistence to safety nets and cash income: exploring the diverse values of non-timber forest products for livelihoods and poverty alleviation. In: Non-Timber Forest Products in the global context (S. Shackleton, C. Shackleton and P. Shanley, eds.), pp 55-82. Springer-Verlag, Amsterdam, Netherlands.

Shrestha N. and Shrestha K.K. 2012. Vulnerability assessment of high-valued medicinal plants in Langtang National Park, Central Nepal. Biodiversity, 13(1): 24-36.

Shrestha U.B. and Bawa K.S. 2013. Trade, harvest, and conservation of caterpillar fungus (Ophiocordyceps sinensis) in the Himalayas. Biological Conservation, 159: 514-520.

StataCorp 2011. Stata Statistical Software: Release 12. College Station, TX: StataCorp LP.

Sunderlin W.D., Angelsen A., Belcher B., Burgers P., Nasi R., Santoso L. and Wunder S. 2005. Livelihoods, forests, and conservation in developing countries: an overview. World Development, 33 : 1383-1402.

UNFCO 2013. District Profile Baitadi. United Nations Field Coordination Office, Far Western Region, Dadeldhura, Nepal. [online] URL: http://un.org.np/district_profile.

Vasisht K., Sharma N. and Maninder K. 2016. Current perspective in the international trade of medicinal plants material: An update. Current Pharmaceutical Design, 22(27): 4288-4366.

Watson M.F., Akiyama S., Ikeda H., Pendry C., Rajbhandari K.R. and Shrestha K.K., eds. 2011. Flora of Nepal, Volume 3. Royal Botanic Garden, Edinburgh, UK. 
Annex 1. Predicators and scoring basis for rapid vulnerability assessment of traded MAPs

\begin{tabular}{|c|c|c|c|c|c|}
\hline \multirow[t]{2}{*}{ Predictors } & \multicolumn{4}{|c|}{ Score (minimum to maximum vulnerability) } & \multirow[t]{2}{*}{ Hypothesis } \\
\hline & 1 & 2 & 3 & 4 & \\
\hline Life form & $\begin{array}{l}\text { Annual or biennial } \\
\text { herb }\end{array}$ & $\begin{array}{l}\text { Perennial herb, } \\
\text { perennial climbing } \\
\text { herb }\end{array}$ & $\begin{array}{l}\text { Shrub, woody } \\
\text { climber }\end{array}$ & Tree & $\begin{array}{l}\text { Slow growing trees are more } \\
\text { vulnerable than fast growing } \\
\text { annual herbs }\end{array}$ \\
\hline Parts used & Leaf & $\begin{array}{l}\text { Fruit, seed, flower, } \\
\text { resin }\end{array}$ & $\begin{array}{l}\text { Bark, stem, } \\
\text { wood }\end{array}$ & $\begin{array}{l}\text { Root, rhizome, } \\
\text { tuber, whole plant }\end{array}$ & $\begin{array}{l}\text { Harvesting of root and whole } \\
\text { plants is more destructive } \\
\text { than harvesting leaves or } \\
\text { fruits and seeds }\end{array}$ \\
\hline $\begin{array}{l}\text { Geographical } \\
\text { distribution }\end{array}$ & Pluri-regional & $\begin{array}{l}\text { Pan-Himalaya and } \\
\text { two other } \\
\text { phytogeographical } \\
\text { domains within } \\
\text { Asia }\end{array}$ & Pan-Himalaya & $\begin{array}{l}\text { Himalayan } \\
\text { endemic }\end{array}$ & $\begin{array}{l}\text { Widely distributed species are } \\
\text { less vulnerable }\end{array}$ \\
\hline $\begin{array}{l}\text { Altitudinal span } \\
\text { (m) }\end{array}$ & $>2400$ & $>1600$ to 2400 & $>800$ to 1600 & $<800$ & $\begin{array}{l}\text { Species with narrow } \\
\text { altitudinal span is more } \\
\text { vulnerable }\end{array}$ \\
\hline $\begin{array}{l}\text { Trade volume } \\
\text { (kg) }\end{array}$ & Up to 100 & $>100-1000$ & $>1000-10000$ & $>10000$ & $\begin{array}{l}\text { Resources are overharvested } \\
\text { to meet the high demand }\end{array}$ \\
\hline $\begin{array}{l}\text { Per unit price } \\
\text { (NRs/kg) }\end{array}$ & Up to 10 & $>10-100$ & $>100-1000$ & $>1000$ & $\begin{array}{l}\text { Higher price tempt harvester } \\
\text { for premature and } \\
\text { overharvesting }\end{array}$ \\
\hline Resource origin & $\begin{array}{l}\text { Only from } \\
\text { cultivation (CC) }\end{array}$ & $\begin{array}{l}\text { Wild and small } \\
\text { scale commercial } \\
\text { cultivation (WCC) }\end{array}$ & $\begin{array}{l}\text { Wild and trial } \\
\text { cultivation } \\
\text { (WTC) }\end{array}$ & $\begin{array}{l}\text { Only wild } \\
\text { harvested (WD) }\end{array}$ & $\begin{array}{l}\text { Resources only harvested } \\
\text { from wild are more } \\
\text { vulnerable }\end{array}$ \\
\hline $\begin{array}{l}\text { Conservation } \\
\text { status }\end{array}$ & Not assigned & In one category & $\begin{array}{l}\text { In two } \\
\text { categories }\end{array}$ & $\begin{array}{l}\text { In more than two } \\
\text { categories }\end{array}$ & $\begin{array}{l}\text { Species assigned in more } \\
\text { conservation categories are } \\
\text { more vulnerable }\end{array}$ \\
\hline $\begin{array}{l}\text { Habitat } \\
\text { specificity }\end{array}$ & $\begin{array}{l}\text { Habitat generalist } 2 \\
\text { (occurring in more } \\
\text { than two habitats } \\
\text { including farmlands } \\
\text { \& wastelands) }\end{array}$ & $\begin{array}{l}\text { Habitat generalist } \\
1 \text { (occurring in } \\
\text { more than } 2 \\
\text { habitats excluding } \\
\text { farmlands \& } \\
\text { wastelands) }\end{array}$ & $\begin{array}{l}\text { Habitat } \\
\text { specialist } 2 \\
\text { (occurring in } \\
\text { more than one } \\
\text { specialized } \\
\text { habitat) }\end{array}$ & $\begin{array}{l}\text { Habitat specialist } 1 \\
\text { (occurring in } \\
\text { single, very specific } \\
\text { habitat) }\end{array}$ & $\begin{array}{l}\text { Plant that grows in specific } \\
\text { habitat are more vulnerable }\end{array}$ \\
\hline $\begin{array}{l}\text { Local } \\
\text { population size }\end{array}$ & Mostly large & $\begin{array}{l}\text { Mostly large, } \\
\text { somewhere small }\end{array}$ & $\begin{array}{l}\text { Mostly small, } \\
\text { somewhere } \\
\text { large }\end{array}$ & Everywhere small & $\begin{array}{l}\text { Species growing in smaller } \\
\text { areas with small population } \\
\text { are more vulnerable }\end{array}$ \\
\hline
\end{tabular}

